\title{
Screening and Molecular Identification of Pectinase Producing Microbes from Coffee Pulp
}

\author{
Oliyad Jeilu Oumer $\mathbb{D D}^{1}$ and Dawit Abate ${ }^{2}$ \\ ${ }^{1}$ Department of Biology, Ambo University, P.O. Box 19, Ambo, Ethiopia \\ ${ }^{2}$ College of Natural Science, Addis Ababa University, P.O. Box 1176, Addis Ababa, Ethiopia \\ Correspondence should be addressed to Oliyad Jeilu Oumer; oliyad.jeilu@ambou.edu.et
}

Received 12 September 2017; Revised 18 January 2018; Accepted 7 February 2018; Published 3 April 2018

Academic Editor: Denise Freire

Copyright (c) 2018 Oliyad Jeilu Oumer and Dawit Abate. This is an open access article distributed under the Creative Commons Attribution License, which permits unrestricted use, distribution, and reproduction in any medium, provided the original work is properly cited.

\begin{abstract}
Application of enzymes in biotechnological process has expanded considerably in recent years. In food and related industry, major importance was being attached to the use of enzymes in upgrading quality, increasing yields of extractive processes, product stabilization, and improvement of flavor and byproduct utilization. Pectinases or pectinolytic enzymes are today one of the upcoming enzymes of the commercial sector. It has been reported that microbial pectinases account for $25 \%$ of the global food enzymes sales. For this reason, this study was undertaken with aims of screening microorganisms for the pectinase activity from coffee pulp samples and molecular identification of the potential pectinolytic isolates. In the present investigation, in total, ninetyfive (95) isolates were identified from thirty coffee pulp samples. Based on characterization on the selective growth media, the isolates were grouped as actinomycete (21.06\%), bacteria (65.26\%), and fungi (13.68\%). Among these, 31.58\% showed colonies surrounded by clear zones which indicate the presence of pectinase activity. After rigorous screening steps, the isolates with high potential pectinase activity were identified molecularly by sequencing $16 \mathrm{~S}$ rDNA region of the isolates. Based on the molecular identifications, about $70 \%$ of the isolates are under genus Bacillus.
\end{abstract}

\section{Introduction}

Enzymes are natural catalysts. They are produced by living organisms to increase the rate of an immense and diverse set of chemical reactions required for life. They are involved in all processes essential for life such as DNA replication and transcription, protein synthesis, metabolism, and signal transduction. Their ability to perform very specific chemical transformation has made them increasingly useful in industrial processes [1].

In nature, microorganisms have been endowed with vast potentials. They produce an array of enzymes, which have been exploited commercially over the years. Today's enzyme technology mostly depends on microbes like bacteria and actinomycetes. Potential microorganisms are highly susceptible to genetic manipulations and hence provide ample scope for strain improvement and for further investigation. Ecofriendly biotechnological processes seem to be very important as far as the modern society is concerned for which microbial enzymes are recognized as efficient tools. Thus we attempted a study to screen and report enzymes producing microbes [2].

The biotechnological potential of pectinolytic enzymes from microorganisms has drawn a great deal of attention from various researchers worldwide as likely biological catalysts in a variety of industrial processes. Pectinolytic enzymes can be applied in various industrial sectors wherever the degradation of pectin is required for a particular process. Several microorganisms have been used to produce different types of pectinolytic enzymes [3]. Microbial pectinases account for $25 \%$ of the global food and industrial enzyme sales $[4,5]$ and their market is increasing day by day. These are used extensively for fruit juice clarification, juice extraction, manufacture of pectin free starch, refinement of vegetable fibers, degumming of natural fibers, wastewater treatment, and cocoa and tobacco and as an analytical tool in the assessment of plant products $[6,7]$. Pectinase treatment accelerates tea fermentation and also destroys the foam forming property 
of instant tea powders by destroying pectins. They are also used in coffee fermentation to remove mucilaginous coat from coffee beans $[8,9]$.

Although use of pectinases in food-processing industries has been fairly well established, the modes of action and experimental utility of several pectin-degrading enzymes have not been explored for applications in human nutrition and health. Prebiotics preferred pectic oligosaccharides during fermentation. Their abilities to protect colonocytes against Escherichia coli verocytotoxins, to stimulate apoptosis in human colonic adenocarcinoma, and to increase Bifidobacteria and Eubacterium rectale numbers with the subsequent increase in butyrate concentrations have also been reported [19].

Almost all the commercial preparations of pectinases are produced from fungal sources. Aspergillus niger is the most commonly used fungal species for industrial production of pectinolytic enzymes. Thus, owing to the enormous potential of pectinase in various sectors of industries whenever degradation of pectin is needed, it is important to undertake research in screening of microorganisms for pectinase production.

Therefore, the present study was conducted with the aims of screening pectinolytic microorganisms from coffee pulp and identifying molecularly using 16S rRNA.

\section{Material and Methods}

2.1. Sample Collection. A total of 30 coffee pulp samples were collected from coffee cherry processing site in Gomma, Jima zone, Ethiopia. The sample collected area is located in Oromia National Regional State of Ethiopia. It is located $390 \mathrm{~km}$ south west of Addis Ababa, which is the capital city of Ethiopia. The altitude of this area ranges from 1,380 to 1,680 meters above sea level; however, some points along the southern and western boundaries have altitudes ranging from 2229 to 2870 meters.

About $100 \mathrm{~g}$ of each sample was collected aseptically using UV-rays sterilized polythene bags. The sample containing bags were sealed and stored into $4^{\circ} \mathrm{C}$ refrigerator in Mycology Laboratory, Addis Ababa University, until the time of the analysis.

2.2. Serial Dilution. Aseptically, $10 \mathrm{~g}$ of Coffee Husk from each sample was pooled out and homogenized in sterile $90 \mathrm{ml}$ distilled water. The homogenized samples were agitated for 1 hour at $120 \mathrm{rpm}$ on INFORS HT Ecotron incubator shaker and then serially diluted until dilutions $10^{-4}$ and $10^{-5}$.

2.3. Media Preparation. Starch casein agar media were prepared by dissolving $10 \mathrm{~g}$ soluble starch, $0.3 \mathrm{~g}$ casein, $2 \mathrm{~g} \mathrm{KNO}_{3}$, $2 \mathrm{~g} \mathrm{NaCl}, 2 \mathrm{~g} \mathrm{~K}_{2} \mathrm{HPO}_{4}, 0.05 \mathrm{~g} \mathrm{MgSO}_{4} \cdot 7 \mathrm{H}_{2} \mathrm{O}, 0.02 \mathrm{~g} \mathrm{CaCO}_{3}$, $0.01 \mathrm{~g} \mathrm{FeSO}_{4} \cdot 7 \mathrm{H}_{2} \mathrm{O}$, and $15 \mathrm{~g}$ agar in $1000 \mathrm{ml}$ of distilled water inside $2 \mathrm{~L}$ Erlenmeyer flask. The $\mathrm{pH}$ of the medium was adjusted to $7.0 \pm 0.5$ using digital $\mathrm{pH}$ meter (OAKTON$\mathrm{pH} 110)$. The media were sterilized at a temperature of $121^{\circ} \mathrm{C}$ for 15 minutes. Finally, about $20-25 \mathrm{ml}$ of the sterilized starch casein agar media was poured on sterile Petri plates in the microbiological hood and allowed to solidify at room temperature.

Nutrient agar media were prepared by dissolving $28 \mathrm{~g}$ of nutrient agar in $1000 \mathrm{ml}$ of distilled water inside $2 \mathrm{~L}$ Erlenmeyer flask. The $\mathrm{pH}$ of the medium was adjusted to $7.0 \pm 0.5$ using digital $\mathrm{pH}$ meter (OAKTON-pH110). The media were sterilized at a temperature of $121^{\circ} \mathrm{C}$ for 15 minutes. Finally, about $20-25 \mathrm{ml}$ of the sterilized nutrient agar media was poured on sterile Petri plates in the microbiological hood and allowed to solidify at room temperature.

Malt extract agar media were prepared by dissolving $50 \mathrm{~g}$ of malt extract agar powder in $1000 \mathrm{ml}$ of distilled water inside $2 \mathrm{~L}$ Erlenmeyer flask. The $\mathrm{pH}$ of the medium was adjusted to $7.0 \pm 0.5$ using digital $\mathrm{pH}$ meter (OAKTON-pH110). The media were sterilized at a temperature of $121^{\circ} \mathrm{C}$ for 15 minutes. After sterilization, the medium allowed to cool up to $50^{\circ} \mathrm{C}$ and supplemented with $1 \mu \mathrm{g} / \mathrm{mL}$ of Chloramphenicol to eliminate the growth of microorganisms other than fungus. Finally, about $20-25 \mathrm{ml}$ of the sterilized malt extract agar media was poured on sterile Petri plates in the microbiological hood and allowed to solidify at room temperature.

2.4. Isolation of Actinomycetes. For the isolation of actinomycetes, $0.1 \mathrm{ml}$ aliquots of samples from appropriate dilutions were inoculated onto sterilized and solidified starch casein agar medium using spread plate method (SCAM). Inoculated plates were incubated aerobically at $30^{\circ} \mathrm{C}$ for 3 days -2 weeks in the INFORS HT Ecotron incubator.

2.5. Isolation of Bacteria. For the isolation of bacteria, $0.1 \mathrm{ml}$ aliquots of samples from appropriate dilutions were inoculated onto sterilized and solidified nutrient agar medium by spread plate method. Inoculated plates were incubated aerobically at $30^{\circ} \mathrm{C}$ for 24-48 hours in the INFORS HT Ecotron incubator.

2.6. Isolation of Fungi. For the isolation of fungi, $0.1 \mathrm{ml}$ aliquots of samples from appropriate dilutions were inoculated on sterilized and solidified malt extract agar medium by spread plate method. Inoculated plates were incubated at $30^{\circ} \mathrm{C}$ for 3-8 days in the INFORS HT Ecotron incubator.

2.7. Purification and Preservation of Cultures. Different colonies were randomly picked from countable plates (SCAM for actinomycetes, nutrient agar for bacteria and malt extract agar for fungi) and purified by repeated streaking on the respective media. Pure cultures of each group of microorganisms were then streaked on slants of respective media and stored at $4^{\circ} \mathrm{C}$ for further study.

2.8. Presumptive Screening of Isolates for the Pectinase Activity. The isolates were preliminarily screened for pectinase activity using pectinase screening agar medium (PSAM). The $\mathrm{pH}$ of the medium was adjusted to $5.5 \pm 0.5$ before sterilization and then autoclaved with a temperature of $121^{\circ} \mathrm{C}$ for 15 minutes. Finally, 20-25 ml of media was poured on sterile Petri dishes in the microbiological hood and allowed to solidify at room temperature. All isolates were streaked into this media and incubated at $30^{\circ} \mathrm{C}$ for 24 hours to 2 weeks. At the end of 
the incubation period, the plates were flooded with $50 \mathrm{mM}$ Potassium iodide-iodine solution. A clear halo zone around the colonies indicates the ability of an isolate to produce pectinase [20].

2.9. Primary Screening of Efficient Pectinase Producing Isolates. All the pectinase positive isolates were screened by inoculating them into the above-mentioned screening media. Using a flamed and cooled cork borer, a disc of actively growing pectinase positive isolate was taken and transferred to the center of screening media and then incubated at $30^{\circ} \mathrm{C}$ for 24 hours to 2 weeks. The ratio of the clear zone diameter to colony diameter during that span of time was measured in order to select isolates with highest pectinase activity. The largest ratio is assumed to contain the highest activity. Those isolates with highest ratio were selected for further screening.

2.10. Secondary Screening of Efficient Pectinase Producing Isolates. Isolates with highest clear zone diameter to colony diameter ratio in the pectin-agar plates were subjected to submerged fermentation using YEP medium. The $\mathrm{pH}$ of the medium, YEP, was adjusted to $7.0 \pm 0.5$ before sterilization and then autoclaved with a temperature of $121^{\circ} \mathrm{C}$ for 15 minutes. A volume of $50 \mathrm{~mL}$ YEP medium in $250 \mathrm{~mL}$ Erlenmeyer flask was inoculated with $1 \%$ inoculum. The inoculated flasks were incubated at $30^{\circ} \mathrm{C}$ on an INFORS HT Ecotron incubator shaker at $120 \mathrm{rpm}$. Samples from inoculated flasks were collected at regular intervals of $24 \mathrm{~h}$ and centrifuged at $10,000 \mathrm{rpm}$ for $5 \mathrm{~min}$ at $4^{\circ} \mathrm{C}$. The supernatant was used for measuring the enzyme activity. The enzyme activity was assayed using sodium acetate buffer, $\mathrm{pH}$ 6.5.

2.11. Pectinase Enzyme Assay. Pectinase enzyme assay was based on the determination of reducing sugars produced as a result of enzymatic hydrolysis of pectin by dinitrosalicylic acid reagent (DNS) method (Miller, 1959). For enzyme assay, $1.5 \mathrm{~mL}$ of freshly grown culture was taken and centrifuged at $10,000 \mathrm{rpm}$ for $5 \mathrm{~min}$. The supernatant $(100 \mu \mathrm{L})$ from the culture broth was served as the source of the enzyme. In addition, substrate was prepared by mixing $0.5 \%(\mathrm{w} / \mathrm{v})$ citrus pectin in $0.1 \mathrm{M}$ of $\mathrm{pH} 7.5$ phosphate buffer.

From the prepared substrate, $900 \mu \mathrm{l}$ was added to three clean labeled test tubes; one for enzyme, one for enzyme blank, and one for reagent blank. Then, $100 \mu$ l of crude enzyme was added to test tube labeled as enzyme and $100 \mu \mathrm{l}$ of distilled water was added to test tube labeled as regent blank while test tube labeled as enzyme blank remained as it was. Then, the test tubes were incubated at $50^{\circ} \mathrm{C}$ for 10 minutes in the water bath. After incubation $2000 \mu \mathrm{l}$ of dinitrosalicylic acid reagent (DNS) was added to the all test tubes to stop the reaction. Meanwhile, into test tube labeled as enzyme blank $100 \mu \mathrm{l}$ of crude enzyme was added after the DNS. Then, all the test tubes were placed in a boiling water bath $\left(92^{\circ} \mathrm{C}\right)$ for 10 minutes. Finally, the tubes were cooled and optical density (OD) was measured using spectrophotometer (JENWAY $6300 \mathrm{UV} / \mathrm{Vis}$ ) at $540 \mathrm{~nm}$. Enzyme activity was measured against enzyme blank and reagent blank. The enzyme unit was defined as the amount of enzyme that catalyzes $\mu \mathrm{mol}$ of galacturonic acid per minute $\left(\mu \mathrm{mol} \mathrm{min}{ }^{-1}\right)$ under the assay conditions.

Relative activity was calculated as the percentage enzyme activity of the sample with respect to the sample for which maximum activity is obtained:

$$
\text { Relative Activity }=\frac{\text { Activity of sample }(U) \times 100}{\text { Maximum enzyme activity }(U)}
$$

2.12. Molecular Identification. The potential isolates which were screened and selected on the primary phase were identified using molecular techniques.

2.13. Genomic DNA Extraction. The potential isolates were inoculated into $50 \mathrm{ml}$ of LB broth (Luria-Bertani) and incubated at $37^{\circ} \mathrm{C}$ for $24-48$ hours. After incubation, they were centrifuged at $5000 \mathrm{rpm}, 4^{\circ} \mathrm{C}$, for $10 \mathrm{~min}$, and cells were collected for genomic DNA extraction. The genomic DNA of the isolates was extracted by using the Bacterial Genomic DNA extraction kit according to the manufacturer protocol (QIAGEN, QIAamp DNA Mini Kit).

2.14. Quantification and Qualification of DNA by Agarose Gel Electrophoresis. The extracted DNA was subjected to agarose gel electrophoresis along with the marker DNA (DNA Ladder) to confirm the quality and quantity. About, $1 \mathrm{~g}$ of agarose weighted and poured into $100 \mathrm{ml}$ of $1 \mathrm{x}$ TAE buffer to make $1 \%$ agarose gel. The solution was heated in a microwave oven until agarose gets dissolved. The agarose solution cooled down for about 5 minutes and $0.5 \mu \mathrm{g} / \mathrm{mL}$ of ethidium bromide (EtBr) added. Then, the agarose solution poured into a gel tray with the well comb in place and it was allowed to solidify. After being solidified, the comb was removed and the gel was placed in an electrophoretic tank consisting of $1 \mathrm{x}$ TBE buffer. About $3 \mu \mathrm{l}$ of the extracted DNA was mixed with $2 \mu \mathrm{l}$ of the gel loading dye (Bromophenol blue) and it was loaded into the agarose gel wells. The gel was then electrophoresed at 100 volts for about 45 minutes and it was observed in a gel documentation system.

2.15. PCR Amplification of the $16 S \mathrm{rRNA}$ Gene. PCR is used to amplify the DNA sequence in between two known sequences. The amplification of 16s rRNA gene of the isolates was carried out using PCR machine. Two specific primers, forward primer $27 \mathrm{~F}\left(5^{\prime}\right.$-(AGA GTT TGA TCM TGG CTC AG)-3') and reverse primer $1492 \mathrm{R}\left(5^{\prime}-(\mathrm{CGG}\right.$ TTA CCT TGT TAC GAC TT) $-3^{\prime}$ ) which are complementary to the known $16 \mathrm{~S}$ rDNA sequences, were used.

2.16. Setting Up the PCR Reaction and PCR Machine. Into the AccuPower ${ }^{\circledR}$ Taq PCR PreMix $(10 \mu$ l the master mix containing 10x Taq buffer, $10 \mathrm{mM}$ dNTPs, $25 \mathrm{mM}$ of $\mathrm{MgCl} 2,1 \mathrm{U}$ of Taq DNA polymerase), $1.5 \mu \mathrm{l}$ of forward primer (27F), $1.5 \mu \mathrm{l}$ of Reverse primer (1492R), $2 \mu \mathrm{l}$ of Genomic DNA, and $5 \mu \mathrm{l}$ of PCR grade water were added and the PCR amplification was done. The thermal cycler was programmed for 35 cycles as follows: (1) initial denaturation, $94^{\circ} \mathrm{C}$ for 2 minutes; (2) amplification, $94^{\circ} \mathrm{C}$ for 45 seconds (denaturation), $56^{\circ} \mathrm{C}$ for 1 minute (annealing), and $72^{\circ} \mathrm{C}$ for 1 minute and 30 seconds 
(extension); (3) final extension, $72^{\circ} \mathrm{C}$ for 5 minutes and then held at $4^{\circ} \mathrm{C}$ until needed.

2.17. Quantification and Qualification of Amplified DNA Samples by Nanodrop. The amplified DNA might contain impurities of RNA and protein that can interfere in the DNA tests. About $10 \mu \mathrm{l}$ of isolated DNA sample was placed into the Nanodrop instrument and quantification and qualification of amplified DNA was done.

2.18. Gene Sequencing and Analysis. The PCR sequence products were purified and sequenced. The obtained sequence data were compared with known sequences in the GenBank using the basic local alignment search tool of the national center for biotechnology information (NCBI). Species were identified based on the percentage similarity with the known species sequences in the data base.

\section{Results}

3.1. Isolation of Microorganisms from Coffee Pulp. To isolate microorganisms from the collected coffee pulp samples, serial dilution, pour plating, and streak plating isolation techniques were used. Subsequently, the isolates were subcultured into their respective selective growth media until pure cultures were isolated. In total, ninety-five (95) isolates were identified from thirty coffee pulp samples. Based on characterization on the selective growth media, the isolates were grouped as actinomycete $(21.06 \%)$, bacteria $(65.26 \%)$, and fungi $(13.68 \%)$. For identification purpose, the isolates were designated by prefix "Btk" and followed by their isolate numbers.

\subsection{Screening Isolates for Pectinase Production}

3.2.1. Presumptive Screening. Subsequent to isolation and purification, the isolates were assessed for pectinase activity using pectinase screening agar medium (PSAM). Among the Ninety-five isolates, $31.58 \%$ showed colonies surrounded by clear zones which indicate the presence of pectinase activity.

3.2.2. Primary Screening. To identify isolates with higher pectinase activity, the ratio between clear zone diameter and colony diameter was calculated. The highest ratio observed was $4.7 \pm 1.2$ by isolate Btk27. Those isolates which scored higher than or equal to $2.0 \pm 1.5$ (Mean $\pm \mathrm{SD}$ ) were considered as high enzyme producers, which accounts for $33.3 \%$ of the pectinase positive isolates (Table 1). These isolates were selected for molecular identification and further screening.

3.2.3. Secondary Screening. In order to further screen the selected isolates from primary screening, submerged fermentation test was performed. Accordingly, subsequent to incubation in YEP media, aliquot samples were taken and assayed for their pectinase activity at $6.5 \mathrm{pH}$ Sodium Acetate buffer. The highest enzyme activities, observed were $7.5 \pm 1.17$ and $7.5 \pm 0.52(\mathrm{U} / \mathrm{ml})$ by isolates Btk 25 and Btk27, respectively (Table 2). The lowest observed enzyme activity was $0.02 \pm$ $0.01(\mathrm{U} / \mathrm{ml})$ by isolate $42 \mathrm{Btk} 71$.
TABLE 1: Primary screening: Isolates clear zone to colony diameter ratio.

\begin{tabular}{lcc}
\hline Sr. number & Isolate & $\begin{array}{c}\text { Clear zone to } \\
\text { colony diameter } \\
\text { ratio* }\end{array}$ \\
\hline 1 & Btk5 & $2.9 \pm 1.1$ \\
2 & Btk23 & $3.5 \pm 1.8$ \\
3 & Btk25 & $2.7 \pm 0.3$ \\
4 & Btk26 & $3.4 \pm 0.7$ \\
5 & Btk27 & $4.7 \pm 1.2$ \\
6 & Btk59 & $3.5 \pm 0.8$ \\
7 & Btk71 & $2.7 \pm 1.3$ \\
8 & Btk73 & $2.0 \pm 1.5$ \\
9 & Btk81 & $2.7 \pm 0.3$ \\
10 & Btk95 & $2.8 \pm 0.9$ \\
${ }^{*}$ Values are mean \pm SD of triplicates. &
\end{tabular}

TABLE 2: Secondary screening: pectinase activity (Unit/ml).

\begin{tabular}{lcc}
\hline Sr. number & Strain number & Enzyme activity $^{*}$ \\
\hline 1 & Btk5 & $3.4 \pm 1.12^{\mathrm{b}}$ \\
2 & Btk23 & $6.6 \pm 1.61^{\mathrm{ba}}$ \\
3 & Btk25 & $7.5 \pm 1.2^{\mathrm{a}}$ \\
4 & Btk26 & $5.2 \pm 0.5^{\mathrm{ba}}$ \\
5 & Btk27 & $7.5 \pm 0.5^{\mathrm{ab}}$ \\
6 & Btk59 & $1.0 \pm 0.4^{\mathrm{b}}$ \\
7 & Btk71 & $0.02 \pm 0.01^{\mathrm{b}}$ \\
8 & Btk73 & $3.1 \pm 1.9^{\mathrm{b}}$ \\
9 & Btk81 & $0.14 \pm 0.01^{\mathrm{b}}$ \\
10 & Btk95 & $0.1 \pm 0.01^{\mathrm{b}}$ \\
\hline
\end{tabular}

(i) ${ }^{*}$ Values are mean \pm S.D. of 3 replicates; (ii) Values followed by different superscripts are significantly different at $(P<0.05)$; (iii) Values followed by same superscripts are not significantly different at $(P<0.05)$.

3.3. Molecular Identification of the Isolates. The amplified PCR products were purified and sequenced. The obtained sequence data were blasted in NCBI database and the likely microorganisms (with lower $E$ value, higher identity percentage and maximum total score) were identified (Table 3 ).

\section{Discussion}

In recent years, the potentials of using microorganisms as biotechnological sources of industrially relevant enzymes have stimulated interest in the exploration of extracellular enzymatic activity in several microorganisms [4]. Pectinase producing microorganisms have advantage over other sources because they can be subjected to genetic and environmental manipulations to increase yield [21]. In this study, potential pectinase producing microorganisms were isolated using serial dilution, pour plating, and streak plating techniques from coffee pulp. Similarly, [22, 23] also followed similar procedures to isolate microorganisms from coffee husk and pulp. Coffee pulp is a fibrous mucilaginous material acquired during the processing of coffee cherries by wet or 
TABLe 3: Blast (Basic Local Alignment Search Tool) table.

\begin{tabular}{|c|c|c|c|c|c|c|}
\hline Isolate & $\begin{array}{c}\text { Molecular } \\
\text { identification }\end{array}$ & $\begin{array}{c}\text { GenBank accession } \\
\text { number }\end{array}$ & $\%$ similarity & Taxonomy & Habitat & Reference \\
\hline Btk5 & $\begin{array}{c}\text { Bacillus } \\
\text { methylotrophicus } \\
\text { strain EGY-SCJ5 }\end{array}$ & KC573497.1 & 97 & Bacillus & $\begin{array}{c}\text { Marine water } \\
\text { sediment, Egypt }\end{array}$ & {$[10]$} \\
\hline Btk23 & $\begin{array}{c}\text { Bacillus pumilus } \\
\text { strain B7 }\end{array}$ & KF641839.1 & 95 & Bacillus & $\begin{array}{c}\text { Camel rumen, } \\
\text { China } \\
\end{array}$ & {$[11]$} \\
\hline Btk25 & $\begin{array}{l}\text { Bacillus subtilis } \\
\text { strain NBT-15 }\end{array}$ & HQ244501.1 & 97 & Bacillus & Penut, China & {$[12]$} \\
\hline Btk26 & $\begin{array}{c}\text { Bacillus } \\
\text { amyloliquefaciens } \\
\text { strain ASAG1 }\end{array}$ & FJ597542 & 95 & Bacillus & Stored corn, China & [13] \\
\hline Btk27 & $\begin{array}{l}\text { Bacillus subtilis } \\
\text { strain NBT-15 }\end{array}$ & HQ244501.1 & 97 & Bacillus & Penut, China & {$[12]$} \\
\hline Btk59 & $\begin{array}{c}\text { Exiguobacterium } \\
\text { sp. Y11 }\end{array}$ & EF177690.1 & 95 & Exiguobacterium & Salt Mine, China & {$[14]$} \\
\hline Btk71 & $\begin{array}{c}\text { Pusillimonas } \\
\text { ginsengisoli strain } \\
\text { DCY28 }\end{array}$ & EF672089.1 & 96 & Pusillimonas & Soil, South Korea & {$[15]$} \\
\hline Btk73 & $\begin{array}{c}\text { Bacillus } \\
\text { methylotrophicus } \\
\text { strain IHB B } 7249\end{array}$ & KJ767354.1 & 97 & Bacillus & $\begin{array}{c}\text { Camellia sinensis } \\
\text { (tea), } \\
\text { India }\end{array}$ & {$[16]$} \\
\hline Btk81 & $\begin{array}{l}\text { Bacillus sp. } \\
\text { SVUNM }\end{array}$ & JX119240.1 & 74 & Bacillus & Mica mines, India & [17] \\
\hline Btk95 & $\begin{array}{c}\text { Staphylococcus sp. } \\
\text { NR7 }\end{array}$ & EU784844.1 & 88 & Staphylococcus & Sausage, China & {$[18]$} \\
\hline
\end{tabular}

dry process, respectively. The presence of proteins, pectin, other sugars, and minerals and its high humidity favor the rapid growth of pectinolytic microorganisms. Moreover, the organic nature of the material makes it an ideal substrate for microbial processes for the production of value-added products [24].

Emerging new applications underline the importance of screening pectinase producing microorganisms with novel properties, greater enzyme activity, and large-scale production of these enzymes [25]. In this study, the isolates were subjected into plate agar and submerged fermentation screening methods to identify potent isolate with highest enzyme activity and enzyme activity with broad $\mathrm{pH}$ ranges. The study is in agreement with [26] reporting plate agar screening method used to screen native isolates for pectinase activity. Mehta et al. [27] screened bacterial strains isolated from soil and samples of vegetable using plate agar and submerged fermentation screening methods.

Pectinases are a heterogeneous group of related enzymes and according to the cleavage site; they are divided into three groups: (1) polygalacturonase; (2) pectin lyase and pectate lyase; (3) pectin esterase [28, 29]. Polygalacturonases (PGases) have been reported in many microorganisms, including Neurospora crassa, Aspergillus sp., and Bacillus sp. $[5,30]$. Pectin esterase is reported in Pseudomonas solanacearum, Aspergillus niger, Lactobacillus lactis, Penicillium occitanis, and A. japonicus[4, 5, 31]. Pectate lyases are produced by many bacteria and some pathogenic fungi. They have been reported in Erwinia carotovora, Pseudomonas syringae, and Bacillus sp. [5, 32]. Pectin lyases have been reported to be produced by Aspergillus japonicus, Penicillium sp., and Aspergillus sp. [5, 30, 33]. In this study, pectinase activity is determined on the basis of measuring the amount of reducing sugar by colorimetric methods specifically using 5 -dinitrosalicylate reagent method. Based on the assay procedures and characteristics of the pectinase, the pectinase of the screened and identified isolates in this study resembles polygalacturonase.

The potential isolates for pectinase production were identified molecularly using the $16 \mathrm{~S}$ rRNA gene. Among the molecularly identified isolates about $70 \%$ of the isolates were under genus of Bacillus. According to Priest (1977), there was a widespread distribution of pectinolytic activity throughout the genus of Bacillus. Some works also had been done to produce pectinase by many strains of these genus [32, 34-37]. In addition, during screening the isolates which secrete the highest quantity of pectinase was also of genus Bacillus. The result is in good agreement with Namasivayam et al. [34] which reported that Bacillus sp. can produce large quantities of extracellular pectinase enzyme. Also, out of the ten molecularly identified isolates, six out of them have percentage similarity on the database $<97 \%$; therefore those isolates might be a novel or a new strain/species [38].

\section{Disclosure}

This article does not contain any studies with human participants or animals performed by any of the authors. 


\section{Conflicts of Interest}

There are no conflicts of interest between the authors.

\section{Acknowledgments}

The authors are delighted to acknowledge Addis Ababa University and Ambo University for their cooperation during this study.

\section{References}

[1] S. Li, X. Yang, S. Yang, M. Zhu, and X. Wang, "Technology prospecting on enzymes: application, marketing and engineering," Computational and Structural Biotechnology Journal, vol. 2, no. 3, p. e201209017, 2012.

[2] S. Vuppu and M. Mishra, "An Overview of Some Reported Soil Enzyme Producing Microorganisms," Indian Journal of Fundamental and Applied Life Sciences, vol. 1, no. 4, pp. 180-86, 2011.

[3] R. S. Jayani, S. K. Shukla, and R. Gupta, "Screening of bacterial strains for polygalacturonase activity: its production by bacillus sphaericus (MTCC 7542)," Enzyme Research, vol. 2010, Article ID 306785, 5 pages, 2010.

[4] R. S. Jayani, S. Saxena, and R. Gupta, "Microbial pectinolytic enzymes: a review," Process Biochemistry, vol. 40, no. 9, pp. 29312944, 2005.

[5] H. A. Murad and H. H. Azzaz, "Microbial pectinases and ruminant nutrition," Research Journal of Microbiology, vol. 6, no. 3, pp. 246-269, 2011.

[6] I. Alkorta, C. Garbisu, M. J. Llama, and J. L. Serra, "Industrial applications of pectic enzymes: a review," Process Biochemistry, vol. 33, no. 1, pp. 21-28, 1998.

[7] S. A. Singh, M. Ramakrishna, and A. G. Appu Rao, "Optimisation of downstream processing parameters for the recovery of pectinase from the fermented bran of Aspergillus carbonarius," Process Biochemistry, vol. 35, no. 3-4, pp. 411-417, 1999.

[8] C. Sieiro, B. García-Fraga, J. López-Seijas, A. F. Da Silva, and T. G. Villa, "Microbial Pectic Enzymes in the Food and Wine Industry, Food Ind. Process. - Methods Equip," 2012, http:// www.intechopen.com/books/food-industrial-processes-methods-and-equipment/microbial-pectic-enzymes-in-the-foodand-wine-industry.

[9] G. Hoondal, R. Tiwari, R. Tewari, N. Dahiya, and Q. Beg, "Microbial alkaline pectinases and their industrial applications: A review," Applied Microbiology and Biotechnology, vol. 59, no. 4-5, pp. 409-418, 2002.

[10] R. A. Amer, F. Mapelli, H. M. El Gendi et al., "Bacterial diversity and bioremediation potential of the highly contaminated marine sediments at el max district (Egypt, mediterranean sea)," BioMed Research International, vol. 2015, 17 pages, 2015.

[11] J. Meerak, H. Iida, Y. Watanabe et al., "Phylogeny of $\gamma$ polyglutamic acid-producing Bacillus strains isolated from fermented soybean foods manufactured in Asian countries," The Journal of General and Applied Microbiology, vol. 53, no. 6, pp. 315-323, 2007.

[12] J. Yue, L. Liu, and Z. Chen, Institution of Plant Protection, Jiangsu Academy Agriculture, Nanjing Jiangsu 210014, China, 2010.

[13] Y. Lin, D. Du, C. Si, Q. Zhao, Z. Li, and P. Li, "Potential biocontrol Bacillus sp. strains isolated by an improved method from vinegar waste compost exhibit antibiosis against fungal pathogens and promote growth of cucumbers," Biological Control, vol. 71, pp. 7-15, 2014.

[14] Y. G. Chen, H. M. Li, Q. Y. Li et al., Phylogenetic Diversity of Culturable Bacteria in the Ancient Salt Deposits of the Yipinglang Salt Mine, P. R. China, 2006.

[15] N. Lodders and P. Kämpfer, "A combined cultivation and cultivation-independent approach shows high bacterial diversity in water-miscible metalworking fluids," Systematic and Applied Microbiology, vol. 35, no. 4, pp. 246-252, 2012.

[16] A. Gulati, S. Sood, and R. Thakur, Plant Pathology and Microbiology Lab, HATS Division, CSIR-Institute of Himalayan Bioresource Technology, Post Box No. 6, Palampur, Himachal Pradesh 176061, India, 2016.

[17] E. Li, C. M. Hamm, A. S. Gulati et al., "Inflammatory bowel diseases phenotype, C. difficile and NOD2 genotype are associated with shifts in human ileum associated microbial composition," PLoS ONE, vol. 7, no. 6, Article ID e26284, 2012.

[18] H. H. Kong, J. Oh, C. Deming et al., “Temporal shifts in the skin microbiome associated with disease flares and treatment in children with atopic dermatitis," Genome Research, vol. 22, no. 5, pp. 850-859, 2012.

[19] M. Khan, E. Nakkeeran, and S. Umesh-Kumar, "Potential application of pectinase in developing functional foods," Annual Review of Food Science and Technology, vol. 4, no. 1, pp. 21-34, 2013.

[20] Q. K. Beg, B. Bhushan, M. Kapoor, and G. S. Hoondal, "Production and characterization of thermostable xylanase and pectinase from Streptomyces sp. QG-11-3," Journal of Industrial Microbiology and Biotechnology, vol. 24, no. 6, pp. 396-402, 2000.

[21] V. Bhardwaj and G. Neelam, "Production, Purification of Pectinase from Bacillus Sp. MBRL576 Isolate and Its Application in Extraction of Juice," International Journal of Science and Research, vol. 3, no. 6, pp. 648-652, 2014.

[22] S. Nayak, M. J. Harshitha, M. Maithili, C. Sampath, H. S. Anilkumar, and C. Vaman Rao, "Isolation and characterization of caffeine degrading bacteria from coffee pulp," Indian Journal of Biochemistry and Biophysics, vol. 11, no. 1, pp. 86-91, 2012.

[23] J. Sumitha and T. Sivakumar, "Development Centre," in Original Research Article Isolation and Characterization of Caffeine Degrading Bacteria from West Karnataka, India, N. Tamil, Ed., vol. 2, pp. 338-346, 2013.

[24] A. Pandey, C. R. Soccol, P. Nigam, D. Brand, R. Mohan, and S. Roussos, "Biotechnological potential of coffee pulp and coffee husk for bioprocesses," Biochemical Engineering Journal, vol. 6, no. 2, pp. 153-162, 2000.

[25] S. Shruti and K. Sudev Mandal, "Optimization of Processing Parameters for Production of Pectinolytic Enzymes from Fermented Pineapple Residue of Mixed Aspergillus Species," Jordan Journal of Biological Sciences, vol. 5, no. 4, pp. 307-314, 2012.

[26] P. Hitha K and D. Girija, "Isolation and Screening of Native Microbial Isolates for Pectinase Activity," International Journal of Science and Research, vol. 3, no. 5, pp. 632-634, 2014.

[27] S. A. Mehta, R. Mitali, S. Nilofer, and P. Nimisha, "Optimization of Physiological Parameters for Pectinase Production From Soil Isolates and Its Applications in Fruit Juice Clarification," Journal of Environmental Research And Development, vol. 7, no. 4, pp. 1539-1546, 2013.

[28] P. K. Yadav, V. K. Singh, S. Yadav, K. D. S. Yadav, and D. Yadav, "In silico analysis of pectin lyase and pectinase sequences," Biochemistry (Moscow), vol. 74, no. 9, pp. 1049-1055, 2009. 
[29] D. J. Osborne, "Advances in Pectin and Pectinase Research," in Annals of Botany, F. Voragen, H. Schols, and R. Visser, Eds., vol. 94, pp. 479-480, The Netherlands: Kluwer Academic Publishers, 2004.

[30] D. R. Kashyap, P. K. Vohra, S. Chopra, and R. Tewari, "Applications of pectinases in the commercial sector: a review," Bioresource Technology, vol. 77, no. 3, pp. 215-227, 2001.

[31] C. Arunachalam and S. Asha, "Pectinolytic Enzyme - A Review of New Studies," Adv. Biotech. J, vol. 561, pp. 1-5, 2010.

[32] D. R. Kashyap, S. Chandra, A. Kaul, and R. Tewari, "Production, purification and characterization of pectinase from a Bacillus sp. DT7," World Journal of Microbiology and Biotechnology, vol. 16, no. 3, pp. 277-282, 2000.

[33] A. Chaudhri and V. Suneetha, "Microbially Derived Pectinases: A Review," IOSR Journal of Pharmacy and Biological Sciences, vol. 2, no. 2, pp. 1-5, 2012.

[34] E. Namasivayam, D. John Ravindar, K. Mariappan, A. jiji, M. Kumar, and R. L. Jayaraj, "Production of extracellular pectinase by bacillus cereus isolated from market solid waste," Journal of Bioanalysis \& Biomedicine, vol. 3, no. 3, pp. 70-75, 2011.

[35] R. M. El-Shishtawy, S. A. Mohamed, A. M. Asiri, A.-B. M. Gomaa, I. H. Ibrahim, and H. A. Al-Talhi, "Solid fermentation of wheat bran for hydrolytic enzymes production and saccharification content by a local isolate Bacillus megatherium," BMC Biotechnology, vol. 14, article no. 29, 2014.

[36] H. Yuanyuan, L. Sixin, H. Xiong, and L. Congfa, "Optimization of Polygalacturonase Production Condition for Bacillus Licheniformis 3 x 05 Using Response Surface," Int Conf Agric Biosyst Eng Adv Biomed Eng, pp. 373-377, 2011.

[37] A. Roosdiana, S. Prasetyawan, C. Mahdi, and S. Sutrisno, "Production and Characterization of Bacillus firmus pectinase," The Journal of Pure and Applied Chemistry Research, vol. 2, no. 1, pp. 35-41, 2013.

[38] P. Yarza, P. Yilmaz, E. Pruesse et al., "Uniting the classification of cultured and uncultured bacteria and archaea using $16 \mathrm{~S}$ rRNA gene sequences," Nature Reviews Microbiology, vol. 12, no. 9, pp. 635-645, 2014. 


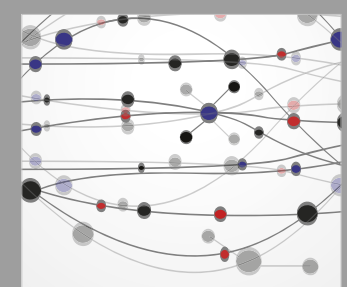

The Scientific World Journal
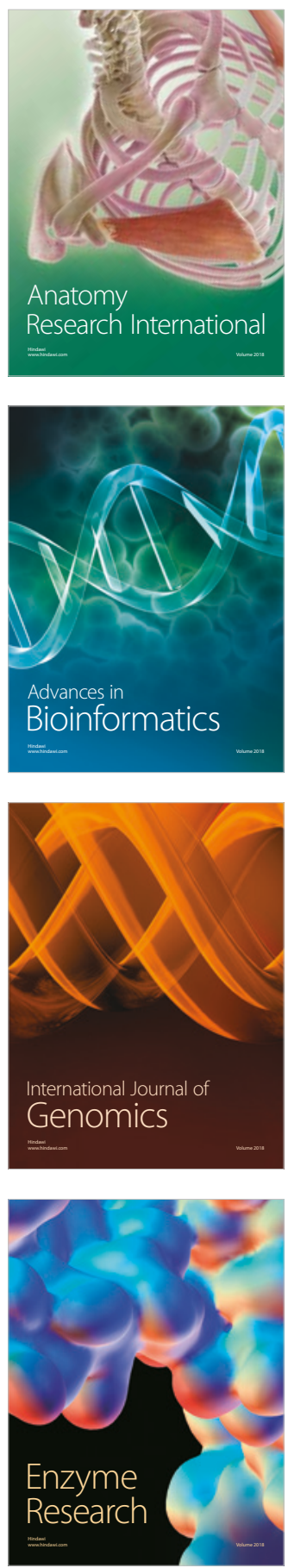
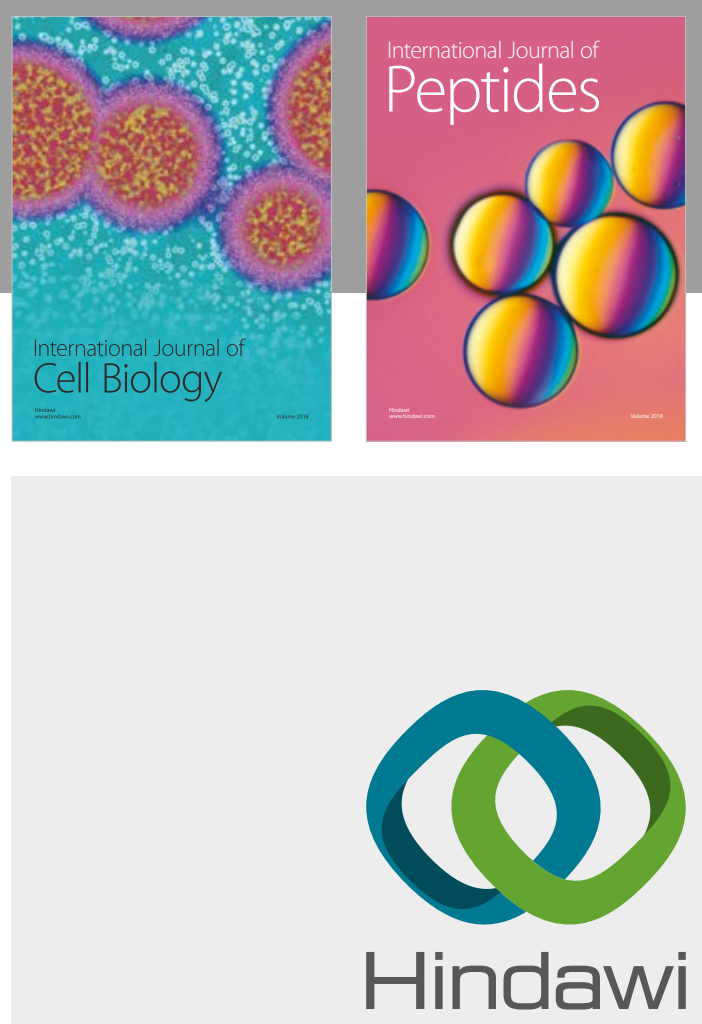

Submit your manuscripts at

www.hindawi.com
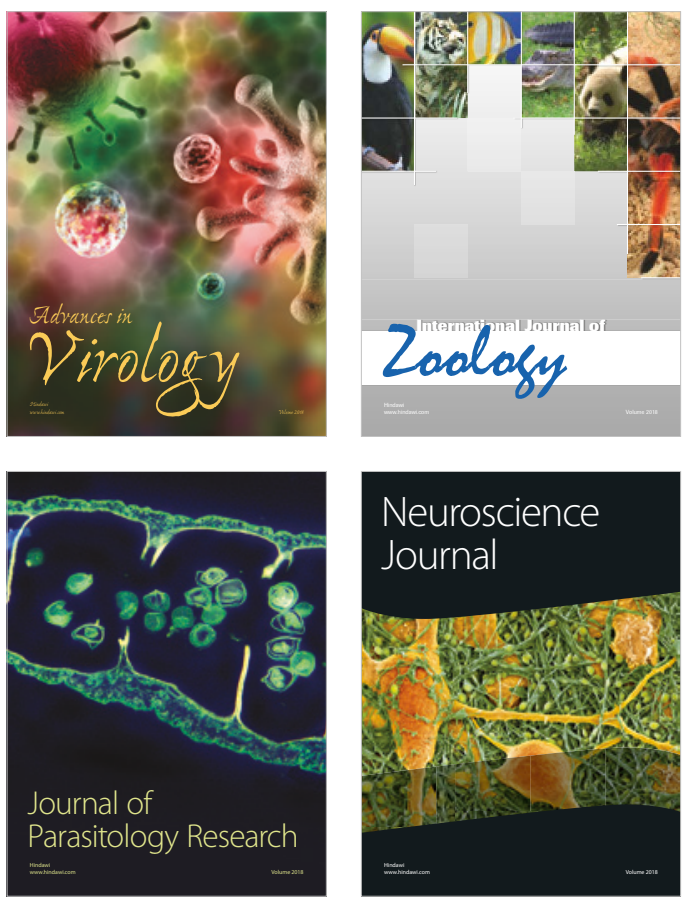
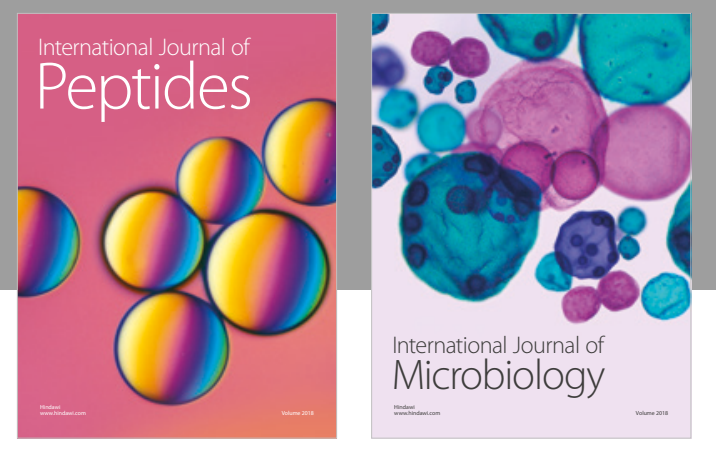

nternational Journal of Microbiology
Journal of
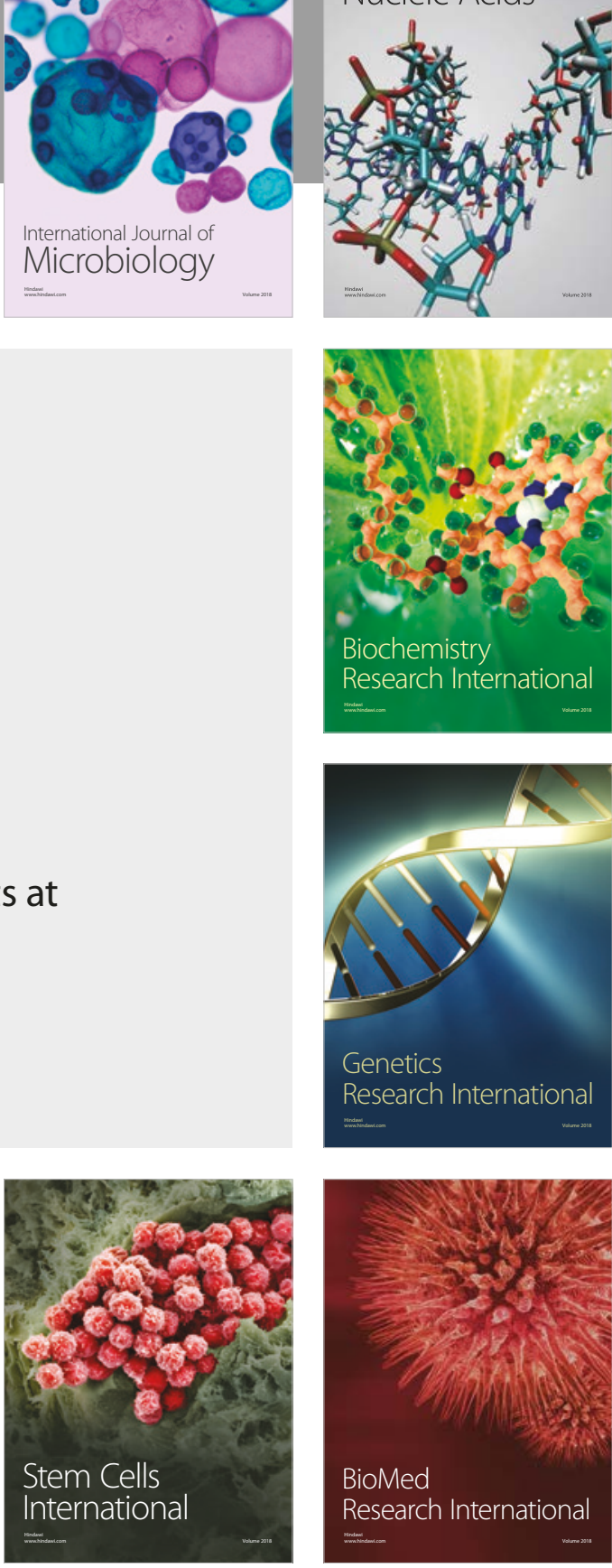
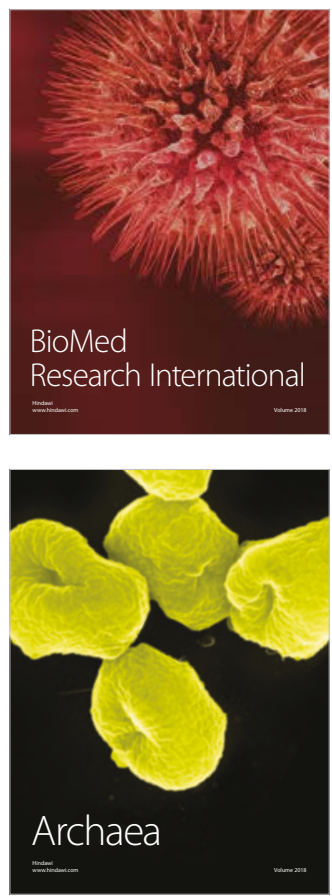